\title{
Fungal Endophyte-Mediated Crop Improvement: The Way Ahead
}

\author{
Vijaya R. Chitnis ${ }^{1 *}$, Trichur S. Suryanarayanan ${ }^{2}$, Karaba N. Nataraja ${ }^{3}$, S. Rajendra Prasad ${ }^{4}$, \\ Ralf Oelmüller ${ }^{5}$ and R. Uma Shaanker ${ }^{1,3 *}$
}

'School of Ecology and Conservation, University of Agricultural Sciences, GKVK, Bangalore, India, ${ }^{2}$ Vivekananda Institute of Tropical Mycology (VINSTROM), Ramakrishna Mission Vidyapith, Chennai, India, ${ }^{3}$ Department of Crop Physiology, University of Agricultural Sciences, GKVK, Bangalore, India, ${ }^{4}$ Department of Seed Science and Technology, University of Agricultural Sciences, GKVK, Bangalore, India, ${ }^{5}$ Plant Physiology, Matthias-Schleiden Institute, Friedrich-Schiller - University, Jena, Germany

Endophytes are non-disease causing microbes (bacteria and fungi) surviving in living tissues of plants. Their intimate association and possible coevolution with their plant partners have resulted in them contributing to an array of plant growth benefits ranging from enhanced growth and biomass accumulation, tolerance to abiotic and biotic stresses

OPEN ACCESS

Edited by:

Xiangming $X u$,

NIAB EMR, United Kingdom

Reviewed by:

Iñigo Zabalgogeazcoa,

Institute of Natural Resources and Agrobiology of Salamanca (IRNASA),

Spain

Matevz Papp-Rupar, NIAB EMR, United Kingdom

*Correspondence:

Vijaya R. Chitnis vijaya.chitnis@outlook.com R. Uma Shaanker umashaanker@gmail.com

Specialty section:

This article was submitted to Crop and Product Physiology,

a section of the journal

Frontiers in Plant Science

Received: 11 May 2020 Accepted: 28 September 2020

Published: 27 October 2020

Citation:

Chitnis VR, Suryanarayanan TS, Nataraja KN, Prasad SR,

Oelmüller R and Shaanker RU (2020)

Fungal Endophyte-Mediated Crop Improvement: The Way Ahead.

Front. Plant Sci. 11:561007.

doi: 10.3389/fp/s.2020.561007 and in nutrient acquisition. The last couple of decades have witnessed a burgeoning literature on the role of endophytes (Class 3 type) in regulating plant growth and development and their adaptation to abiotic and biotic stresses. Though the underlying mechanisms of plant-endophyte interactions are far from clear, several studies have raised the hope of their potential application in agriculture, especially in mitigating abiotic and biotic stresses. The use of endophytes is envisaged as a route to reduce the production cost and burden on the environment by lessening the dependence on breeding for crop improvement and agrochemicals. Unfortunately, save a few well documented examples of their use, a little of these insights has been translated into actual agricultural applications. Here, we reflect on this paucity and elaborate on some of the important bottlenecks that might stand in way of fully realizing the potential that endophytes hold for crop improvement. We stress the need to study various facets of the endophyte-plant association for their gainful application in agriculture.

Keywords: agriculture, abiotic stress, biotic stress, agrochemicals, crop breeding

\section{INTRODUCTION}

Endophytes are microbes residing within plants without causing any harm to their growth and development. Unlike disease-causing microorganisms, endophytes are non-pathogenic and many of them are known to enhance their plant host's fitness (Mendes et al., 2013; Philippot et al., 2013). Fungal endophytes (FE) are classified in to four Classes based on their symbiotic criteria (Rodriguez et al., 2009). Class 1 endophytes are Clavicipitaceous fungi which survive in some cool season grasses and are transmitted vertically with their seeds. Class 2 endophytes colonize extensively the shoot, root, and rhizome of many plants and are transmitted both vertically and horizontally. Class 3 endophytes have a broad host range exhibiting restricted colonization of the shoot; they are transmitted horizontally. Class 4 endophytes which are also horizontally transmitted are restricted to the roots. The Class 3 endophytes which we address 
here, are effective in combating several abiotic stresses faced by their host plants, such as drought, salinity, nutrient deficiency, and metal toxicity, etc., and biotic stresses caused by pathogens and insect pests (Waller et al., 2005; Hardoim et al., 2008; Rho et al., 2018a; Manasa et al., 2020; Sampangi-Ramaiah et al., 2020). They are also known to produce pharmaceutically important secondary metabolites and enzymes (Shweta et al., 2010; Kusari et al., 2013; Kaushik et al., 2014; Kumara et al., 2014; Nagarajan et al., 2014; Uzma et al., 2019) and phytohormones (Bilal et al., 2017, 2018). In the past few decades, it became obvious that endophytes could be isolated from every plant studied (Strobel and Daisy, 2003; Hardoim et al., 2015; Suryanarayanan et al., 2018a; Giauque et al., 2019). These analyses showed that many attributes of endophytes, in particular their universal occurrence, sustained presence in plants, non-pathogenic nature, ability to enhance the biotic and abiotic stress tolerance of their plant hosts (Rodriguez et al., 2009), increase access to soil nutrients and increase the plant yield (White et al., 2019; Xia et al., 2019) project them as candidates holding high promise for use in crop improvement. Despite this, very few of the benefits associated with endophytes have been translated into real-world agricultural applications. Here, we reflect upon this gap and identify potential bottlenecks that might hinder the exploitation of endophytes in agricultural applications. We also discuss the possible approaches that might help pave the way ahead in allowing for a gainful application of endophytes in agriculture.

\section{PROOF OF THE PRINCIPLE OF APPLICATION OF ENDOPHYTES IN AGRICULTURE}

Although fungal endophyte presence in plants is well known, the mechanism of plant colonization by these fungi is hardly known. For instance, the ability of species of Colletotrichum, Guignardia, Pestalotiopsis, Diaporthe, and Xylaria to infect a wide range of plant species as foliar endophyte (Suryanarayanan et al., 2018a) has not been explained. One study shows that an endophytic Pestalotiopsis produces a chitin deacetylase enzyme, which modifies its chitin cell wall to escape detection by its plant host immune system (Cord-Landwehr et al., 2016). Yuan et al. (2019), based on transcriptomics and proteomics analysis conclude that the endophyte Gilmaniella sp. infects its host plant Atractylodes lancea by reducing its immune response. A leaf is usually colonized by many Class 3 endophyte species (Rodriguez et al., 2009) exhibiting restricted growth in the tissue. Of these, invariably one or two species dominate the endophyte assemblage of the leaf, while the rest occur as satellite species with low colonization frequencies (Suryanarayanan et al., 2018a; Vaz et al., 2018). The interactions of a foliar endophyte with co-occurring endophytes (fungal and bacterial) in the leaf are little understood. It is possible that such interactions among them as well as their cross talk with the host would ultimately define the composition and ecological functions of the endophytes. According to Schulz et al. (2015), a balanced antagonism operates among the various endophytes in a plant tissue to maintain the endophyte community. For instance, an endophytic Alternaria tenuissima produced more antifungal polyketide stemphyperylenol in the presence of another endophyte, Nigrospora sphaerica (Chagas et al., 2013). Colonization by alien endophytes of a plant tissue is generally inhibited by the existing native endophytes (Mohandoss and Suryanarayanan, 2009; Suryanarayanan et al., 2018b).

Additionally, since the plant and its associated microbiome (which includes the endophytes) function as a mini ecosystem (the holobiome), to use endophytes gainfully it is essential to discern the different interactions operating here. Currently, there is very little information available on the functional aspect plant and its microbiome (Vandenkoornhuyse et al., 2015). We hardly know the roles of the core (dominant) and satellite (showing low degree of tissue colonization) endophyte species or of the ecological functions of key stone species in an endophyte assemblage. Plants generally resist infection by pathogens through pathogen-associated molecular pattern (PAMP)-triggered immunity (PTI) or effector-triggered immunity (ETI). The basic question of how the endophytes overcome such resistance responses while infecting the host has not been answered satisfactorily (Vandenkoornhuyse et al., 2015). This is intriguing since some symptomless pathogens infect plant tissues and survive as endophytes.

Despite such lacunae, work conducted over the last 2 decades across a range of agricultural crop plants has provided a strong proof of principle for the application of endophytes to agriculture (Suryanarayanan et al., 2017). The goal of this review is to highlight some of the salient studies to reiterate the potential application of endophytes in agriculture but not to review the literature on plant/endophyte interactions.

Laboratory experiments and glasshouse trials strongly indicate that endophytes could mitigate stresses in agriculturally important crops and increase productivity. A recent meta-analysis by Rho et al. (2018a) highlights the potential applications of endophytes in mitigating drought, salinity, and nutrient shortfalls in agricultural systems. For instance, inoculation of FE from wild barley in to a barley cultivar significantly increased its grain yield (Murphy et al., 2018). Treatment of wheat plants with the endophyte Alternaria alternata enhanced growth and imparted drought tolerance. Plants colonized by the endophyte effectively quenched stress-induced free radicals and also accumulated higher levels of osmolytes (Qiang et al., 2019). Growth promotion induced by endophyte could often be brought about indirectly as evident in peanut plants where the endophyte, Phomopsis liquidambri enhanced nodulation and nitrogen fixation by $\mathrm{H}_{2} \mathrm{O}_{2}$ and NO signaling (Xie et al., 2017). FE protect crops against abiotic stresses under laboratory conditions, as shown for salt (Baltruschat et al., 2008; Manasa et al., 2020; Sampangi-Ramaiah et al., 2020), heat and drought (Redman et al., 2002; Bailey et al., 2006; Hubbard et al., 2014; Ali et al., 2018; Sangamesh et al., 2018) stresses. A number of studies confirm that the root endophyte Piriformospora indica (Serendipita indica) ameliorates a broad range of abiotic stresses in many crop plants. In Zea mays, it solubilizes the insoluble phosphate in the soil, which is unavailable to the plant and transports it to the plant (Yadav et al., 2010; Aslam et al., 2019), increases the drought stress tolerance of barley (Ghaffari et al., 2019), 
and, apart from improving stress tolerance, increases growth and nutrient acquisition in soybean plants (Bajaj et al., 2018). Endophytes also enhance tolerance of host plants to biotic stressors including pathogenic fungi (Botrytis cinerea in grapevine - Barka et al., 2002; Phytophthora sp. in cocoa - Arnold et al., 2003; Cronartium ribicola in Pinus monticola - Ganley et al., 2008; Verticillium dahliae in tomato - Fakhro et al., 2010, and Phytophthora capsici in hot pepper - Bae et al., 2011). The protection of plants against insect pests is well documented for Class 1 FE (Rodriguez et al., 2009), which are vertically transmitted within their grass host communities (Rodriguez et al., 2009; Kauppinen et al., 2016; Raman and Suryanarayanan, 2017), although, according to Faeth and Fagan (2002), such endophytes may not function as defensive mutualists in native plants. A few horizontally transmitted Class 3 FE are also reported to reduce insect attack of plants (Vega, 2008; Vidal and Jaber, 2015). The action of endophytes in plants may often be due to the synergy with other co-existing endophytes, fungi, or bacteria as was demonstrated by Bilal et al. (2020). They showed that the two EF, Paecilomyces formosus and Pencillium funiculosum acted synergistically to impart tolerance to drought, high temperature, and heavy metals (Bilal et al., 2020).

The underlying mechanisms of the benefits of endophytes on their host plants are currently being unraveled. It appears that a combination of alterations in the gene expression and physiology of the host induced by the endophyte is reflected as the plant's response to stresses. But much of the studies investigating the mechanisms are largely restricted to a few fungi, notably the root endophyte, Pirimiforma indica. For example, in rice, $P$. indica confers drought tolerance by regulating miR159/miR396 that target $\mathrm{MYB}$ and GRF transcription factors, involved in regulation of growth and hyposensitivity response (Mohseni Fard et al., 2017). In yet another study in rice, $P$. indica colonization led to the differential miRNA synthesis that targeted transcription factors involved in nutrient uptake, $\mathrm{Na}^{+}$transport, and growth regulation including auxin responsive proteins (Kord et al., 2019). In soybean, $P$. indica colonization leads to the upregulation of genes within the phenylpropanoid and derivative pathway and in iron scavenging siderophores (Bajaj et al., 2018). More recently, a comparative transcriptome analysis of rice colonized by a salt adapted EF was shown to upregulate a number of genes involved in both abiotic and biotic stress tolerance, when the plants were subjected to salinity stress (SampangiRamaiah et al., 2020). There is now increasing evidence that the endophyte effects on plants are mediated through specific signaling cascades which, upon perception by the host cell, alter host gene expression (Sampangi-Ramaiah et al., 2020).

Infection of a plant by FE rapidly upregulates defense related genes and the lignin and cellulose content of its cell walls (Soliman et al., 2013; Mejía et al., 2014); such responses of the plant as well as the chemicals of the resident endophyte enhance its ability to counter abiotic and biotic stressors (Estrada et al., 2013). Thus, it is apparent that the use of endophytes is a promising route for improving crop productivity by reducing the dependence on breeding and agrochemicals. However, the cost suffered by the plant for harboring endophytes is a facet that has not been understood adequately. For the plant host, the presence of FE results in reduced photosynthesis, altered host nitrogen metabolism, and loss of photosynthates (Mejía et al., 2014). Alternatively, the hypothesis that respiratory $\mathrm{CO}_{2}$ of endophytes could result in islands of low photorespiration thus enhancing photosynthesis in the leaf tissue (Suryanarayanan, 2013) appears to be true at least with reference to bacterial endophytes (Rho et al., 2018b). To fully appreciate the benefit accrued by endophyte association, the cost-benefit ratio for a plant should ideally be worked out by taking into account the entire community of endophyte it harbors.

In summary there is ample evidence to suggest that endophytes can mediate growth and other benefits such as adaptation to abiotic and biotic stresses in plants that could in principle lead to their gainful application in agriculture.

\section{FROM THE LAB TO THE FIELD: STILL A CHASM}

Long term studies confirm that plant association with mycorrhizal fungi is not accidental and results in increased stress tolerance of the associated plant (Gehring et al., 2017). It is conceivable that the adaptive capabilities of the host plant increase substantially due to the extensive metabolic potential of the associated mycorrhizal fungi (Lau et al., 2017). Such focused studies on endophyte association are lacking though endophyte technology has distinct advantage over inorganic agriculture practices. Since most of the endophytes used in agriculture colonize the underground and above ground tissues and develop together with their host plants, their metabolisms are adapted to each other. The balanced interactions during the entire symbiotic phase allows for better adaptation to environmental changes since the responses are the result of a synergistic interaction between the two partners, which is believed to be more than the sum of the responses of the two partners alone (Rosenberg and Zilber-Rosenberg, 2018). However, the successful use of these microbes depends largely on their performance under field conditions which now requires extensive research addressing the barriers for effective product development.

There are many publications endorsing the positive role of FE on plant growth and performance in adverse environments (Gundel et al., 2013). Epichloë (Class 1) endophyte strains selected for low toxicity to livestock and which increase the productivity of forage grasses and the robustness of turf grasses have been used in the United States, Australia, and New Zealand (Young et al., 2014; Kauppinen et al., 2016). The performance of Epichloë endophytes infected grasses is superior such that Kauppinen et al. (2016) assert their use while designing sustainable management strategies for agriculture. According to Johnson et al. (2013) endophyte mediated plant trait improvement contributed around \$200 million per annum to the economy of New Zealand. Root endophytic Trichoderma species increase yields of stressed crops by inducing biochemical pathways, which render the toxic reactive oxygen species generated during stress into less toxic compounds 
(Harman et al., 2020). Despite such studies, with reference to non-Epichloë endophytes, there is very little by way of commercial products which are evident in the global market. To evaluate this, we searched the United States and Indian patent database to analyze patents filed with respect to endophyte treatment for plant health benefits. The comprehensive search was made using the keywords "endophyte" and "plant" and the exclusive patents typically describing the effective utilization of endophytes for plant benefits are compiled in Table $\mathbf{1}^{1}$

We observed that a considerable number of fungal endophytes were acclaimed to improve the overall agronomic attributes; sometimes, an endophyte confers more than one beneficial effect on plant growth and yield. For example, in one case endophytes not only improved drought tolerance, but also reduced pest attack, and improved the yield attributes in cotton (United States patent \# 9,277,751; Table 1). Many FE control pests and diseases in plants (Table 1). Only four

${ }^{1}$ http://patft.uspto.gov/netahtml/PTO/search-bool.html; accessed on March 19, 2019 patents are listed in the Indian database, ${ }^{2}$ of which only that of Arora et al. (2015) has been experimentally examined and approved (Table 2).

We contacted 66 authors referred to in the meta-analysis publication of Rho et al. (2018a) and obtained responses from eight scientists, of which one claimed translation of the research into a commercial product (Cheng et al., 2012). This demonstrates that product development is disappointingly low compared to the scientific investments. As mentioned by one respondent, the complex and protracted regulatory guidelines are mainly responsible for the low success rate in commercialization of the product developed by the scientific community.

Finally, we also compiled information on commercial endophytic products, which are already available in the market. An example is endophyte infected grasses commercialized by a New Zealand based company "Grasslanz". ${ }^{3}$ The inoculation of an endophyte in the grass grown in airports and recreational

${ }^{2} \mathrm{http}$ //ipindiaservices.gov.in/publicsearch; accessed on March 20, 2019 ${ }^{3}$ http://www.grasslanz.com/

TABLE 1 | United States patents claiming endophyte's benefit in plants (2000-2018).

\begin{tabular}{|c|c|c|c|c|}
\hline No & Organism & Patent claim & Patent \# & Patent author \\
\hline \multicolumn{5}{|c|}{ A. Endophytic fungi } \\
\hline 1 & Neotyphodium & Resistance to invertebrate pests & $61,11,170$ & Latch et al., 2000 \\
\hline 2 & Fungi & $\begin{array}{l}\text { Insect resistance, disease resistance, drought } \\
\text { resistance }\end{array}$ & $61,80,855$ & Hiruma, 2001 \\
\hline 3 & $\begin{array}{l}\text { Neotyphodium spp. or } \\
\text { Gliocladium spp. }\end{array}$ & $\begin{array}{l}\text { Insect resistance, disease resistance to Italian rye } \\
\text { grass }\end{array}$ & $65,48,745$ & Hiruma et al., 2003 \\
\hline 4 & Neotyphodium spp. & Pest control, no toxicity to grazing animal & $68,05,859$ & Imada et al., 2004 \\
\hline 5 & $\begin{array}{l}\text { Muscodor albus and } \\
\text { Muscodor roseus }\end{array}$ & Pest control by volatiles & $69,11,338$ & Strobel et al., 2005 \\
\hline 6 & Muscodor albus & Bio control of fungus & $77,54,203$ & Strobel et al., 2010 \\
\hline 7 & Neotyphodium Iolii & $\begin{array}{l}\text { No ryegrass toxicosis, enhance growth under } \\
\text { drought }\end{array}$ & $79,76,857$ & Tapper et al., 2011 \\
\hline 8 & Colletotrichum dematium & Antifungal peptide & $80,80,256$ & Strobel et al., 2011 \\
\hline 9 & $\begin{array}{l}\text { Muscodor albus and } \\
\text { Muscodor roseus }\end{array}$ & Disease and nematode resistance by volatile & $80,93,024$ & Strobel et al., 2012 \\
\hline 10 & Colletotrichum dematium & $\begin{array}{l}\text { Biological activity against either Botrytis cinerea, } \\
\text { Sclerotinia sclerotiorum, or Rhizoctonia solani }\end{array}$ & $87,65,147$ & Strobel et al., 2014 \\
\hline 11 & Acremonium spp. & $\begin{array}{l}\text { Protection of grass plants from biotic or abiotic } \\
\text { stress }\end{array}$ & $89,75,489$ & Carven, 2015 \\
\hline 12 & Clonostachys rosea & $\begin{array}{l}\text { Stimulation of nodules in legumes, enhanced } \\
\text { plant growth under stress }\end{array}$ & $81,01,551$ & Stewart et al., 2012 \\
\hline & & Increased boll retention, growth, and yield. & & \\
\hline 13 & Dothideomycetes spp. & $\begin{array}{l}\text { Resistance to drought, cold, metal, salt, fungi, } \\
\text { bacteria, virus and pests in cotton }\end{array}$ & $92,77,751$ & Sword, 2016 \\
\hline 14 & Neotyphodium Iolii & $\begin{array}{l}\text { No ryegrass toxicosis, protection from pests and/ } \\
\text { or abiotic stress }\end{array}$ & $93,74,973$ & Tapper et al., 2016 \\
\hline 15 & Lophodermium spp. & Antifungal activity in pine & $94,69,836$ & Miller et al., 2016 \\
\hline 16 & Phialocephala spp. & Pest tolerance in conifers & $95,49,528$ & Miller et al., 2017 \\
\hline 17 & Sarocladium spp. & $\begin{array}{l}\text { Promotion of germination, resistance to nitrogen } \\
\text { stress }\end{array}$ & $96,87,001$ & Vujanovic et al., 2017 \\
\hline 18 & Neotyphodium coenophialum & $\begin{array}{l}\text { No ergopeptide, black beetle resistance, } \\
\text { enhanced biomass and yield in grasses }\end{array}$ & $97,06,779$ & Roulund et al., 2017 \\
\hline 19 & $\begin{array}{l}\text { Incertaesedis, Nectriaceae, or } \\
\text { Plectosphaerellaceae }\end{array}$ & $\begin{array}{l}\text { Improved tolerance to drought, pests, better } \\
\text { yield in cotton }\end{array}$ & $97,56,865$ & Sword, 2017 \\
\hline 20 & Acremonium spp. & $\begin{array}{l}\text { Improved resistance to diseases and/or pests in } \\
\text { Brachiariaurochloa grass }\end{array}$ & $98,72,502$ & Spangenberg et al., 2018 \\
\hline 21 & Trichoderma harzianum & $\begin{array}{l}\text { Enhanced growth or seed germination under } \\
\text { abiotic stress }\end{array}$ & $99,61,904$ & Rodriguez et al., 2018 \\
\hline
\end{tabular}


TABLE 2 | Indian patents claiming endophyte's benefit in plants (2000-2018).

\begin{tabular}{|c|c|c|c|c|}
\hline No & Organism & Patent claim & Patent \# & Patent author \\
\hline \multicolumn{5}{|c|}{ A. Endophytic fungi } \\
\hline 1 & $\begin{array}{l}\text { Piriformospora indica and } \\
\text { Azotobacter chroococcum }\end{array}$ & Plant growth promotion & 2017/DEL/2013 & Arora et al., 2015 \\
\hline \multicolumn{5}{|c|}{ B. Endophytic fungi + Bacteria } \\
\hline 2 & Fungi and bacteria & $\begin{array}{l}\text { Patent awaiting improvement of germination } \\
\text { rate, emergence rate, shoot biomass, root } \\
\text { biomass, seedling root length, seedling shoot } \\
\text { length, and yield. }\end{array}$ & 201717043115 & Karen et al., 2017 \\
\hline 3 & Fungi and bacteria & $\begin{array}{l}\text { Patent awaiting improvement of } \\
\text { agronomically important traits. }\end{array}$ & 201717043114 & Karen et al., 2018 \\
\hline
\end{tabular}

areas deter insects, grazing animals, and birds. The "Grasslanz" homepage claims over 69 and $88 \%$ reduction in above and below ground insect pests, respectively. This application might be a long-term solution for bird strike issues in the airports. ${ }^{4}$ Another example comes from "BioEnsure" developed by Adaptive Symbiotic Technologies (Seattle, United States). "BioEnsure" is endophytic fungal based preparation which had shown between 3 and 30\% increase in crop (corn, rice, wheat, soybean, and cotton) yield under drought, heat, and cold stresses. ${ }^{5}$

\section{BOTTLENECKS AND WAY FORWARD}

Taking FE as a standard, we discuss the constraints faced in using endophytes for crop improvement (Figure 1). The two basic steps for successful use of FE in crop improvement are: (1) the identification of a FE with a needed trait and (2) introduction of that FE into the crop which involves colonization, establishment, and confirmation of a successful symbiosis and sustained expression of the desired trait in FE-colonized crops (Hyde et al., 2019). The first step is straight forward and involves screening of FE isolated from plants for choice traits. The second step is fraught with uncertainties since it entails the interaction of the newly introduced FE with the crop host and its already existing endobiome. Here, the vertically transmitted grass endophyte Epichloë appears to be more tractable owing to its tight host specificity and systemic and sustained infection of the host (Saikkonen et al., 2016) though certain questions like the role of genetics in dictating the fungus-grass symbiosis and its effect on natural and agricultural grass ecosystems remain unanswered (Saikkonen et al., 2016). Relatively less information is available on the interactions of horizontally transmitted endophytes with their hosts. Although the broad host range of some of these like Colletotrichum, Guignardia (Phyllosticta), Pestalotiopsis, Diaporthe (Phomopsis), and Xylaria could be a salient feature in ensuring successful colonization of different crops, their influence on the native microbes of the host crop and higher trophic levels are not known. (Rabiey et al., 2019). Furthermore, many species of these FE genera are latent pathogens and it is possible that climate change

${ }^{4} \mathrm{http} / /$ www.grasslanz.com/understanding-the-science

${ }^{5} \mathrm{cf}$. http://www.adaptivesymbiotictechnologies.com/field-results.html could tilt their lifestyle toward pathogenicity (Moricca and Ragazzi, 2008; Paolinelli-Alfonso et al., 2016). These facets of FE interactions should be unraveled for their efficient use in agriculture. Suffice it to say that little information with agricultural relevance is available for this step. Cogitation on the plant's defense reactions toward biotrophic and necrotophic fungal pathogens at the structural, biochemical, and genome levels could be of heuristic value here.

First, as many fungi including endophytes produce toxic secondary metabolites including mycotoxins (Thirumalai et al., $2013,2020)$, it is necessary to evaluate endophytes for the production of such metabolites when they are introduced in to crop plants; this becomes even more important if the endophytes reach the edible parts of the plant, such as the seeds or tuber (for human consumption) or forage (for animal consumption; Figure 1). Second, there is little information on the interplay that operates between the newly introduced microbes and the native plant endobiome. Hardly any information is available on the infection of a plant host by an endophyte, which is the very first step of FE establishment. One explanation for the colonization of a wide range of plants by non-host specific FE is that they escape detection by the plant immune response by altering the chitin in their cell wall, while infecting the plant (Cord-Landwehr et al., 2016). Endophyte enrichment technology should ensure that the introduced endophyte establishes itself in the plant host endobiome and its introduction does not perturb the native microbiome, which could result in negative impacts on plant performance or the environment/ ecosystem or agrosystem (Figure 1). For instance, the presence of non-native endophytes which have not coevolved with the host could eliminate the native beneficial microbes resulting in a net loss for the plant (Whipps, 2001). Galls in trees induced by wasps are abscised by necrosis induced by the fungal endophyte Apiognomonia errabunda; however, this is more harmful to the host than the galls (Sieber, 2007). Thus, it is essential to consider the plant as a holobiont, i.e., the plant together with the diversity of microbes interacting with the plant and each other to achieve FE mediated enhance plant performance (Rosenberg and Zilber-Rosenberg, 2018; Rabiey et al., 2019).

The plant and its microbiome have to be considered as a mini-ecosystem in which the microbiome can be the essential determinant for plant performance (Agler et al., 2016). For example, Thynne et al. (2019) showed that fungal pathogens 

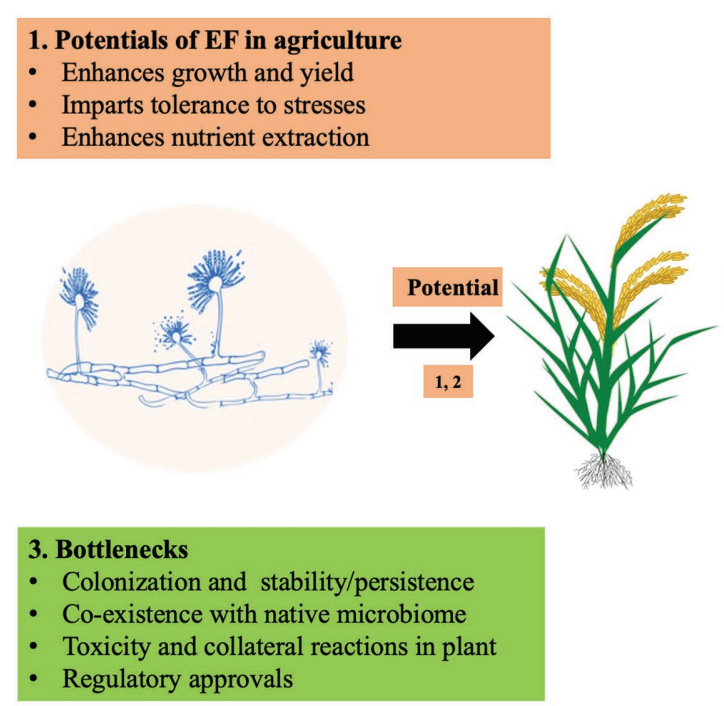

2. Advantages of EF technology

- Reduces carbon footprint

- Environmentally safe

- Farmer friendly; easy to use technology

FIGURE 1 | Schematic illustration of the potentials and bottlenecks of application of endophytes in agriculture. Please see text for explanation.

harboring horizontally acquired modular polyketide genes from bacteria exhibit a broader host range than those that are not housing these trans-genes. This highlights the importance of short-term and long-term interactions between plant and microbes and might have an important influence on the survival of a newly introduced endophyte. Furthermore, in the halophyte Salicornia europaea, the fungal endophyte community is influenced by the bacterial community but not vice versa (Furtado et al., 2019). Endophytes which do not produce antibiotics in pure cultures do so when co-cultured with another endophyte species (Schulz et al., 2015) suggesting that microbial interactions can profoundly influence the endobiome. It is conceivable that the complex network of such interactions (Schulz et al., 2015) can result in warding off the introduced non-native endophyte in the crop, or that the newly introduced endophyte alters the endobiome community such that it is no longer beneficial for the plant. The report that mango leaves could be colonized by alien FE species only after the native EF species are eliminated by systemic fungicide treatment is an example for the importance for this scenario (Mohandoss and Suryanarayanan, 2009). Similarly, an FE from a brown seaweed which effectively controls the insect pest Helicoverpa armigera in crops does not survive in the new host, even after infection with high spore doses, probably due to its poor competitive ability with the native microbiome (Suryanarayanan et al., 2018b). Alternatively, it is reasonable to assume that a new endophyte can dominate the holobiome and restrict growth of the endogenous microbes, which can result in loss of benefits for the plants. In this context, it is important to mention that barely anything is known about the role of newly introduced endophytes on existing mycorrhiza in crop plants, although many examples demonstrate that both symbionts can co-exist in the same root. Yet another factor to be considered is the possible negative effect of an introduced endophyte which could nullify the beneficial effect provided by it (Rabiey et al., 2019).
These include lack of substantial information on (1) field performance of endophytes, (2) influence of weather conditions on endophyte performance, (3) highly restricted colonization of plants leading to only localized results, and (4) alteration in the native community of associated microbes by the endophyte leading to reduced performance of the hoist (Rabiey et al., 2019).

Third, it is necessary to lay caution on the possibility that an introduced endophyte may elicit disease reactions in a non-host plant. Fungi such as Leptosphaerulina crassiasca (Suryanarayanan and Murali, 2006) and Fusarium verticillioides (Oren et al., 2003) could live in a plant as endophytes or pathogens. Endophytes alter their lifestyle depending on host genotype, web of interactions, the experience with co-occurring microbes in the endobiome, and the environmental conditions (Hardoim et al., 2015). Symptomless FE could become pathogenic due to heat stress such as that produced by climate change (Paolinelli-Alfonso et al., 2016). Factors which determine the lifestyle of a microbe in its host environment and influence its expression profile need to be understood to effectively use FE in crop management (Figure 1). Such investigations can be done in three directions - by analyzing the influences of the host milieu, of the microbes with and without the host, and of environmental conditions in which the crop is growing. Furthermore, for FE to be important for agricultural applications, it should be ensured that endophyte formulations maintain substantial viability and activity (Woodward et al., 2012). They also have to be consistent with cultural practices since agrochemicals can have a strong influence on EF communities associated with crops (Stuart et al., 2018).

Finally, crop breeding programs have not considered beneficial microbiota yet (Bakker et al., 2012; Raaijmakers and Mazzola, 2016), and genetic markers favoring endophyte association with crops are not known. Plant genetic loci controlling endophyte colonization in crop plants might be a helpful tool to promote agriculture with less agrochemical usage. Since information on 
the influence of agricultural practices on FE of crops is meager, the performance of FE in real field situations cannot be predicted. A recent study reports that pest and pathogen management alters the leaf microbiome diversity of tea (Cernava et al., 2019). Agricultural practices including fertilizer application and mowing frequency influence the FE communities in agriculturally important grasses (Wemheuer et al., 2019). Application of agrochemicals such as triflumuron and fenoxaprop-P-ethyl decreases the diversity, richness, and evenness of FE in soybean (da Costa Stuart et al., 2018). Gange et al. (2019), conclude that although endophytes could be crucial players in plant protection, experimental methodology, and inoculation methods to reintroduce FE into plant can skew the results. Since environment and agricultural practices influence interactions within the endobiome, these factors have to be taken into consideration for using FE in crop improvement (Figure 1). Since plant genotype influences the diversity and composition of its microbiome (Li et al., 2018), an FE effective for one crop may not be suitable for other crops. Hence, developing crop varieties which would readily accommodate an introduced FE will improve crop production and productivity (Schlatter et al., 2017).

Another formidable challenge for many biofertilizers, biopesticides, or bio-stimulants used in agriculture is obtaining registration for the product. The licensing laws differ with countries and registration may involve several regulatory bodies which is time-consuming (Timmusk et al., 2017). Therefore, this non-biological bottleneck requires more efficient administration such that research on endophyte-mediated crop improvement could be galvanized (Harman et al., 2010).

\section{CONCLUSION}

From the disparate studies so far, it seems that a deep understanding of the holobiont ecology and breeding of crops for better association with beneficial microbes (particularly endophytes) is the ideal way forward. Commercialization of

\section{REFERENCES}

Agler, M. T., Ruhe, J., Kroll, S., Morhenn, C., Kim, S. -T., Weigel, D., et al. (2016). Microbial hub taxa link host and abiotic factors to plant microbiome variation. PLoS Biol. 14:e1002352. doi: 10.1371/journal.pbio.1002352

Ali, A. H., Abdelrahman, M., Radwan, U., El-Zayat, S., and El-Sayed, M. A. (2018). Effect of Thermomyces fungal endophyte isolated from extreme hot desert-adapted plant on heat stress tolerance of cucumber. Appl. Soil Ecol. 124, 155-162. doi: 10.1016/j.apsoil.2017.11.004

Arnold, A. E., Mejía, L. C., Kyllo, D., Rojas, E. I., Maynard, Z., Robbins, N., et al. (2003). Fungal endophytes limit pathogen damage in a tropical tree. Proc. Natl. Acad. Sci. U. S. A. 100, 15649-15654. doi: 10.1073/pnas.2533483100

Arora, M., Abdin, Z. M., and Varma, A. (2015). Plant growth promoting root endophyte. Indian Patent Application No. 2017/DEL/2013. New Delhi, Intellectual Property India, Government of India.

Aslam, M. M., Karanja, J., and Bello, S. K. (2019). Piriformospora indica colonization reprograms plants to improved P-uptake, enhanced crop performance, and biotic/abiotic stress tolerance. Physiol. Mol. Plant Pathol. 106, 232-237. doi: 10.1016/j.pmpp.2019.02.010

Bae, H., Roberts, D. P., Lim, H. -S., Strem, M. D., Park, S. -C., Ryu, C. -M., et al. (2011). Endophytic Trichoderma isolates from tropical environments endophytes and/or their products can promote plant fitness and agricultural yields. In spite of an increasing demand for these biological products in today's market, we still need to address various gridlocks related to basic mechanisms of newly introduced FE into plants and eco-agrosystems. Field applications will help to understand whether results from the laboratory reflect those from the real world, in particular under adverse climate conditions.

\section{AUTHOR CONTRIBUTIONS}

RS along with VC planned the review. VC collated the data and prepared the draft. TS contributed to redrafting the manuscript and adding substantially to the section on the bottlenecks and way-forward and straightening the bibliography. $\mathrm{KN}$, SP, and RO edited and contributed to several rounds of revision of the manuscript. All authors contributed to the article and approved the submitted version.

\section{FUNDING}

The work reported is supported by an ICAR (Indian Council of Agricultural Research) - CAAST (Centre for Advanced Agricultural Science \& Technology), Activity1 1c-"Next generation technologies for micro-biome enabled seed priming" (ICAR_NAHEP; F. No. NAHEP/CAAST/2018-19; AB/AC7703) grant. VC and RS were supported by an ICAR Emeritus Scientist Grant to RS.

\section{ACKNOWLEDGMENTS}

The authors would like to thank the University of Agricultural Sciences, Bangalore for facilitating collaborative efforts. Ms. Ayesha Begum's help in developing the illustration in Figure 1 is gratefully acknowledged.

delay disease onset and induce resistance against Phytophthora capsici in hot pepper using multiple mechanisms. Mol. Plant-Microbe Interact. 24, 336-351. doi: 10.1094/MPMI-09-10-0221

Bailey, B. A., Bae, H., Strem, M. D., Roberts, D. P., Thomas, S. E., Crozier, J., et al. (2006). Fungal and plant gene expression during the colonization of cacao seedlings by endophytic isolates of four Trichoderma species. Planta 224, 1449-1464. doi: 10.1007/s00425-006-0314-0

Bajaj, R., Huang, Y., Gebrechristos, S., Mikolajczyk, B., Brown, H., Prasad, R., et al. (2018). Transcriptional responses of soybean roots to colonization with the root endophytic fungus Piriformospora indica reveals altered phenylpropanoid and secondary metabolism. Sci. Rep. 8:10227. doi: 10.1038/ s41598-018-26809-3

Bakker, M. G., Manter, D. K., Sheflin, A. M., Weir, T. L., and Vivanco, J. M. (2012). Harnessing the rhizosphere microbiome through plant breeding and agricultural management. Plant Soil 360, 1-13. doi: 10.1007/s11104-012-1361-x

Baltruschat, H., Fodor, J., Harrach, B. D., Niemczyk, E., Barna, B., Gullner, G., et al. (2008). Salt tolerance of barley induced by the root endophyte Piriformospora indica is associated with a strong increase in antioxidants. New Phytol. 180, 501-510. doi: 10.1111/j.1469-8137.2008.02583.x

Barka, E. A., Gognies, S., Nowak, J., Audran, J. -C., and Belarbi, A. (2002). Inhibitory effect of endophyte bacteria on Botrytis cinerea and its influence 
to promote the grapevine growth. Biol. Control 24, 135-142. doi: 10.1016/ s1049-9644(02)00034-8

Bilal, L., Asaf, S., Hamayun, M., Gul, H., Iqbal, A., Ullah, I., et al. (2018). Plant growth promoting endophytic fungi Asprgillusfumigatus TS1 and Fusariumproliferatum BRL1 produce gibberellins and regulates plant endogenous hormones. Symbiosis 76, 117-127. doi: 10.1007/s13199-018-0545-4

Bilal, S., Khan, A. L., Shahzad, R., Asaf, S., Kang, S. M., and Lee, I. J. (2017). Endophytic Paecilomyces formosus LHL10 augments Glycine max L. adaptation to ni-contamination through affecting endogenous phytohormones and oxidative stress. Front. Plant Sci. 8:870. doi: 10.3389/fpls.2017.00870

Bilal, S., Shahzad, R., Imran, M., Jan, R., Kim, K. M., and Lee, I. J. (2020). Synergistic association of endophytic fungi enhances Glycine max L. resilience to combined abiotic stresses: heavy metals, high temperature and drought stress. Ind. Crop. Prod. 143:111931. doi: 10.1016/j.indcrop.2019.111931

Cernava, T., Chen, X., Krug, L., Li, H., Yang, M., and Berg, G. (2019). The tea leaf microbiome shows specific responses to chemical pesticides and biocontrol applications. Sci. Total Environ. 667, 33-40. doi: 10.1016/j. scitotenv.2019.02.319

Chagas, F. O., Dias, L. G., and Pupo, M. T. (2013). A mixed culture of endophytic fungi increases production of antifungal polyketides. J. Chem. Ecol. 39, 1335-1342. doi: 10.1007/s10886-013-0351-7

Cheng, Z., Woody, O. Z., McConkey, B. J., and Glick, B. R. (2012). Combined effects of the plant growth-promoting bacterium Pseudomonas putida UW4 and salinity stress on the Brassica napus proteome. Appl. Soil Ecol. 61, 255-263. doi: 10.1016/j.apsoil.2011.10.006

Cord-Landwehr, S., Melcher, R. L. J., Kolkenbrock, S., and Moerschbacher, B. (2016). A chitin deacetylase from the endophytic fungus Pestalotiopsis sp. efficiently inactivates the elicitor activity of chitin oligomers in rice cells. Sci. Rep. 6:38018. doi: 10.1038/srep38018

da Costa Stuart, A. K., Stuart, R. M., and Pimentel, I. C. (2018). Effect of agrochemicals on endophytic fungi community associated with crops of organic and conventional soybean (Glycine max L. Merril). Agric. Nat. Resour. 52, 388-392. doi: 10.1016/j.anres.2018.10.005

Estrada, C., Wcislo, W. T., and Van Bael, S. A. (2013). Symbiotic fungi alter plant chemistry that discourages leaf-cutting ants. New Phytol. 198, 241-251. doi: $10.1111 / \mathrm{nph} .12140$

Faeth, S. H., and Fagan, W. F. (2002). Fungal endophytes: common host plant symbionts but uncommon mutualists. Integr. Comp. Biol. 42, 360-368. doi: $10.1093 / \mathrm{icb} / 42.2 .360$

Fakhro, A., Andrade-Linares, D. R., von Bargen, S., Bandte, M., Büttner, C., Grosch, R., and Schwarz, D., P. Franken (2010). Impact of Piriformospora indica on tomato growth and on interaction with fungal and viral pathogens. Mycorrhiza 20, 191-200. doi: 10.1007/s00572-009-0279-5

Furtado, B. U., Gołębiewski, M., Skorupa, M., Hulisz, P., and Hrynkiewicz, K. (2019). Bacterial and fungal endophytic microbiomes of Salicornia europaea. Appl. Environ. Microbiol. 85:e00305-19. doi: 10.1128/AEM.00305-19

Gange, A. C., Koricheva, J., Currie, A. F., Jaber, L. R., and Vidal, S. (2019). Meta-analysis of the role of entomopathogenic and unspecialized fungal endophytes as plant bodyguards. New Phytol. 223, 2002-2010. doi: 10.1111/ nph.15859

Ganley, R. J., Sniezko, R. A., and Newcombe, G. (2008). Endophyte-mediated resistance against white pine blister rust in Pinus monticola. For. Ecol. Manag. 255, 2751-2760. doi: 10.1016/j.foreco.2008.01.052

Gehring, C. A., Sthultz, C. M., Flores-Rentería, L., Whipple, A. V., and Whitham, T. G. (2017). Tree genetics defines fungal partner communities that may confer drought tolerance. Proc. Natl. Acad. Sci. U. S. A. 114, 11169-11174. doi: 10.1073/pnas.1704022114

Ghaffari, M. R., Mirzaei, M., Ghabooli, M., Khatabi, B., Wu, Y., Zabet-Moghaddam, M., et al. (2019). Root endophytic fungus Piriformospora indica improves drought stress adaptation in barley by metabolic and proteomic reprogramming. Environ. Exp. Bot. 157, 197-210. doi: 10.1016/j.envexpbot.2018.10.002

Giauque, H., Connor, E. W., and Hawkes, C. V. (2019). Endophyte traits relevant to stress tolerance, resource use and habitat of origin predict effects on host plants. New Phytol. 221, 2239-2249. doi: 10.1111/nph.15504

Gundel, P. E., Pérez, L. I., Helander, M., and Saikkonen, K. (2013). Symbiotically modified organisms: nontoxic fungal endophytes in grasses. Trends Plant Sci. 18, 420-427. doi: 10.1016/j.tplants.2013.03.003

Hardoim, P. R., van Overbeek, L. S., Berg, G., Pirttilä, A. M., Compant, S., Campisano, A., et al. (2015). The hidden world within plants: ecological and evolutionary considerations for defining functioning of microbial endophytes. Microbiol. Mol. Biol. Rev. 79, 293-320. doi: 10.1128/MMBR.00050-14

Hardoim, P. R., van Overbeek, L. S., and van Elsas, J. D. (2008). Properties of bacterial endophytes and their proposed role in plant growth. Trends Microbiol. 16, 463-471. doi: 10.1016/j.tim.2008.07.008

Harman, G., Doni, F., Khadka, R., and Uphoff, N. (2020). Endophytic strains of Trichoderma increase plants' photosynthetic capability. J. Appl. Microbiol. doi: 10.1111/jam.14368 [Epub ahead of print]

Harman, G. E., Obregón, M. A., Samuels, G. J., and Lorito, M. (2010). Changing models for commercialization and implementation of biocontrol in the developing and the developed world. Plant Dis. 94, 928-939. doi: 10.1094/ PDIS-94-8-0928

Hubbard, M., Germida, J. J., and Vujanovic, V. (2014). Fungal endophytes enhance wheat heat and drought tolerance in terms of grain yield and second-generation seed viability. J. Appl. Microbiol. 116, 109-122. doi: 10.1111/ jam. 12311

Hyde, K. D., Xu, J., Rapior, S., Jeewon, R., Lumyong, S., Niego, A. G. T., et al. (2019). The amazing potential of fungi: 50 ways we can exploit fungi industrially. Fungal Divers. 97, 1-136. doi: 10.1007/s13225-019-00430-9

Johnson, L. J., de Bonth, A. C. M., Briggs, L. R., Caradus, J. R., Finch, S. C., Fleetwood, D. J., et al. (2013). The exploitation of epichloae endophytes for agricultural benefit. Fungal Divers. 60, 171-188. doi: 10.1007/s13225-013-0239-4

Kauppinen, M., Saikkonen, K., Helander, M., Pirttilä, A. M., and Wäli, P. R. (2016). Epichloë grass endophytes in sustainable agriculture. Nat. Plants 2:15224. doi: 10.1038/nplants.2015.224

Kaushik, N. K., Murali, T. S., Sahal, D., and Suryanarayanan, T. S. (2014). A search for antiplasmodial metabolites among fungal endophytes of terrestrial and marine plants of southern India. Acta Parasitol. 59, 745-757. doi: 10.2478/s11686-014-0307-2

Kord, H., Fakheri, B., Ghabooli, M., Solouki, M., Emamjomeh, A., Khatabi, B., et al. (2019). Salinity-associated microRNAs and their potential roles in mediating salt tolerance in rice colonized by the endophytic root fungus Piriformospora indica. Funct. Integr. Genomics 19, 659-672. doi: 10.1007/ s10142-019-00671-6

Kumara, P. M., Shweta, S., Vasanthakumari, M. M., Sachin, N., Manjunatha, B. L., Jadhav, S. S., et al. (2014). "Endophytes and plant secondary metabolite synthesis: molecular and evolutionary perspective" in Advances in endophytic research. eds. V. Verma and A. Gange (New Delhi: Springer), 177-190.

Kusari, S., Pandey, S. P., and Spiteller, M. (2013). Untapped mutualistic paradigms linking host plant and endophytic fungal production of similar bioactive secondary metabolites. Phytochemistry 91, 81-87. doi: 10.1016/j. phytochem.2012.07.021

Lau, J. A., Lennon, J. T., and Heath, K. D. (2017). Trees harness the power of microbes to survive climate change. Proc. Natl. Acad. Sci. U. S. A. 114, 11009-11011. doi: 10.1073/pnas.1715417114

Li, Y., Wu, X., Chen, T., Wang, W., Liu, G., Zhang, W., et al. (2018). Plant phenotypic traits eventually shape its microbiota: a common garden test. Front. Microbiol. 9:2479. doi: 10.3389/fmicb.2018.02479

Manasa, K. M., Vasanthakumari, M. M., Nataraja, K. N., and Uma Shaanker, R. (2020). Endophytic fungi of salt adapted Ipomeapes-caprae L. R. Br: their possible role in inducing salinity tolerance in paddy (Oryza sativa L.). Curr. Sci. 118, 1448-1453. doi: 10.18520/cs/v118/i9/1448-1453

Mejía, L. C., Herre, E. A., Sparks, J. P., Winter, K., García, M. N., Van Bael, S. A., et al. (2014). Pervasive effects of a dominant foliar endophytic fungus on host genetic and phenotypic expression in a tropical tree. Front. Microbiol. 5:479. doi: 10.3389/fmicb.2014.00479

Mendes, R., Garbeva, P., and Raaijmakers, J. M. (2013). The rhizosphere microbiome: significance of plant beneficial, plant pathogenic, and human pathogenic microorganisms. FEMS Microbiol. Rev. 37, 634-663. doi: 10.1111/ 1574-6976.12028

Mohandoss, J., and Suryanarayanan, T. S. (2009). Effect of fungicide treatment on foliar fungal endophyte diversity in mango. Sydowia 61, 11-24.

Mohseni Fard, E., Ghabooli, M., Mehri, N., and Bakhshi, B. (2017). Regulation of miR159 and miR396 mediated by Piriformospora indica confer drought tolerance in rice. J. Plant Mol. Breed 5, 10-18. doi: 10.22058/ JPMB.2017.60864.1129

Moricca, S., and Ragazzi, A. (2008). Fungal endophytes in Mediterranean oak forests: a lesson from Discula quercina. Phytopathology 98, 380-386. doi: 10.1094/PHYTO-98-4-0380 
Murphy, B. R., Doohan, F. M., and Hodkinson, T. R. (2018). From concept to commerce: developing a successful fungal endophyte inoculant for agricultural crops. J. Fungi 4:24. doi: 10.3390/jof4010024

Nagarajan, A., Thirunavukkarasu, N., Suryanarayanan, T. S., and Gummadi, S. N. (2014). Screening and isolation of novel glutaminase free L-asparaginase from fungal endophytes. Res. J. Microbiol. 9, 163-176. doi: 10.3923/ jm.2014.163.176

Oren, L., Ezrati, S., Cohen, D., and Sharon, A. (2003). Early events in the Fusarium verticillioides-maize interaction characterized by using a green fluorescent protein-expressing transgenic isolate. Appl. Environ. Microbiol. 69, 1695-1701. doi: 10.1128/AEM.69.3.1695-1701.2003

Paolinelli-Alfonso, M., Villalobos-Escobedo, J. M., Rolshausen, P., Herrera-Estrella, A., Galindo-Sánchez, C., López-Hernández, J. F., et al. (2016). Global transcriptional analysis suggests Lasiodiplodia theobromae pathogenicity factors involved in modulation of grapevine defensive response. BMC Genomics 17:615. doi: 10.1186/s12864-016-2952-3

Philippot, L., Raaijmakers, J. M., Lemanceau, P., and van der Putten, W. H. (2013). Going back to the roots: the microbial ecology of the rhizosphere. Nat. Rev. Microbiol. 11, 789-799. doi: 10.1038/nrmicro3109

Qiang, X., Ding, J., Lin, W., Li, Q., Xu, C., Zheng, Q., et al. (2019). Alleviation of the detrimental effect of water deficit on wheat (Triticum aestivum L.) growth by an indole acetic acid-producing endophytic fungus. Plant Soil 439, 73-391. doi: 10.1007/s11104-019-04028-7

Raaijmakers, J. M., and Mazzola, M. (2016). Soil immune responses. Science 352, 1392-1393. doi: 10.1126/science.aaf3252

Rabiey, M., Hailey, L. E., Roy, S. R., Grenz, K., Al-Zadjali, M. A. S., Barrett, G. A., et al. (2019). Endophytes vs tree pathogens and pests: can they be used as biological control agents to improve tree health? Eur. J. Plant Pathol. 155, 711-729. doi: 10.1007/s10658-019-01814-y

Raman, A., and Suryanarayanan, T. S. (2017). Fungus-plant interaction influences plant-feeding insects. Fungal Ecol. 29, 123-132. doi: 10.1016/j. funeco.2017.06.004

Redman, R. S., Sheehan, K. B., Stout, R. G., Rodriguez, R. J., and Henson, J. M. (2002). Thermotolerance generated by plant/fungal symbiosis. Science 298:1581. doi: $10.1126 /$ science. 1072191

Rho, H., Doty, S. L., and Kim, S. -H. (2018b). Estimating microbial respiratory $\mathrm{CO}_{2}$ from endophytic bacteria in rice. Plant Signal. Behav. 13:e1500067. doi: 10.1080/15592324.2018.1500067

Rho, H., Hsieh, M., Kandel, S. L., Cantillo, J., Doty, S. L., and Kim, S. -H. (2018a). Do endophytes promote growth of host plants under stress? A meta-analysis on plant stress mitigation by endophytes. Microb. Ecol. 75, 407-418. doi: 10.1007/s00248-017-1054-3

Rodriguez, R. J., White, J. F. Jr., Arnold, A. E., and Redman, R. S. (2009). Fungal endophytes: diversity and functional roles. New Phytol. 182, 314-330. doi: $10.1111 /$ j.1469-8137.2009.02773.x

Rosenberg, E., and Zilber-Rosenberg, I. (2018). The hologenome concept of evolution after 10 years. Microbiome 6:78. doi: 10.1186/ s40168-018-0457-9

Saikkonen, K., Young, C. A., Helander, M., and Schardl, C. L. (2016). Endophytic Epichloë species and their grass hosts: from evolution to applications. Plant Mol. Biol. 90, 665-675. doi: 10.1007/s11103-015-0399-6

Sampangi-Ramaiah, M. H., Jagadheesh, Dey, P., Jambagi, S., Vasantha Kumari, M. M., Oelmüller, R., et al. (2020). An endophyte from salt-adapted Pokkali rice confers salt-tolerance to a salt-sensitive rice variety and targets a unique pattern of genes in its new host. Sci. Rep. 10:3237. doi: 10.1038/ s41598-020-59998-x

Sangamesh, M. B., Jambagi, S., Vasanthakumari, M. M., Shetty, N. J., Kolte, H., Ravikanth, G., et al. (2018). Thermotolerance of FE isolated from plants adapted to the Thar Desert, India. Symbiosis 75, 135-147. doi: 10.1007/ s13199-017-0527-y

Schlatter, D., Kinkel, L., Thomashow, L., Weller, D., and Paulitz, T. (2017). Disease suppressive soils: new insights from the soil microbiome. Phytopathology 107, 1284-1297. doi: 10.1094/PHYTO-03-17-0111-RVW

Schulz, B., Haas, S., Junker, C., Andrée, N., and Schobert, M. (2015). Fungal endophytes are involved in multiple balanced antagonisms. Curr. Sci. 109, 39-45.

Shweta, S., Zuehlke, S., Ramesha, B. T., Priti, V., Mohana Kumar, P., Ravikanth, G., et al. (2010). Endophytic fungal strains of Fusarium solani, from Apodytes dimidiata E. Mey.exArn (Icacinaceae) produce camptothecin, 10-hydroxycamptothecin and 9-methoxycamptothecin. Phytochemistry 71, 117-122. doi: 10.1016/j.phytochem.2009.09.030

Sieber, T. N. (2007). Endophytic fungi in forest trees: are they mutualists? Fungal Biol. Rev. 21, 75-89. doi: 10.1016/j.fbr.2007.05.004

Soliman, S. S., Trobacher, C. P., Tsao, R., Greenwood, J. S., and Raizada, M. N. (2013). A fungal endophyte induces transcription of genes encoding a redundant fungicide pathway in its host plant. BMC Plant Biol. 13:93. doi: 10.1186/1471-2229-13-93

Strobel, G., and Daisy, B. (2003). Bioprospecting for microbial endophytes and their natural products. Microbiol. Mol. Biol. Rev. 67, 491-502. doi: 10.1128/ MMBR.67.4.491-502.2003

Stuart, A. K., Stuart, R. M., and Pimentel, I. C. (2018). Effect of agrochemicals on endophytic fungi community associated with crops of organic and conventional soybean (Glycine max L. Merril). Agric. Nat. Resour. 52, 388-392. doi: 10.1016/j.anres.2018.10.005

Suryanarayanan, T. S. (2013). Endophyte research: going beyond isolation and metabolite documentation. Fungal Ecol. 6, 561-568. doi: 10.1016/j. funeco.2013.09.007

Suryanarayanan, T. S., Devarajan, P. T., Girivasan, K. P., Govindarajulu, M. B., Kumaresan, V., Murali, T. S., et al. (2018a). The host range of multi-host endophytic fungi. Curr. Sci. 115, 1963-1969. doi: 10.18520/cs/v115/ i10/1963-1969

Suryanarayanan, T. S., Gopalan, V., Uma Shaanker, R., Sengupta, A., and Ravikanth, G. (2017). “Translating endophyte research to applications: prospects and challenges." in Diversity and benefits of microorganisms from the tropics. eds. J. L. de Azevedo and M. C. Quecine (Springer: Cham), 343-365.

Suryanarayanan, T. S., Govinda Rajulu, M. B., and Vidal, S. (2018b). Biological control through fungal endophytes: gaps in knowledge hindering success. Curr. Biotechnol. 7, 185-198. doi: 10.2174/2211550105666160504130322

Suryanarayanan, T. S., and Murali, T. S. (2006). Incidence of Leptosphaerulina crassiasca in symptomless leaves of peanut in southern India. J. Basic Microbiol. 46, 305-309. doi: 10.1002/jobm.200510126

Thirumalai, E., Dastjerdi, R., Döll, K., Venkatachalam, A., Karlovsky, P., and Suryanarayanan, T. S. (2013). "Mycotoxins of endophytic Fusarium mangiferae and F. pallidoroseum from betel leaves (Piperbetle L.)" in 35th Mycotoxin workshop; May 22-24, 2013; Ghent, Belgium.

Thirumalai, E., Venkatachalam, A., and Suryanarayanan, T. S. (2020). Fungal endophytes of betel leaves: the need to study mycotoxin-producing endophytes in leafy vegetables. Sydowia (in press).

Thynne, E., Mead, O. L., Chooi, Y. -H., McDonald, M. C., and Solomon, P. S. (2019). Acquisition and loss of secondary metabolites shaped the evolutionary path of three emerging phytopathogens of wheat. Genome Biol. Evol. 11, 890-905. doi: 10.1093/gbe/evz037

Timmusk, S., Behers, L., Muthoni, J., Muraya, A., and Aronsson, A. -C. (2017). Perspectives and challenges of microbial application for crop improvement. Front. Plant Sci. 8:49. doi: 10.3389/fpls.2017.00049

Uzma, F., Mohan, C. D., Siddaiah, C. N., and Chowdappa, S. (2019). "Endophytic fungi: promising source of novel bioactive compounds" in Advances in endophytic fungal research. ed. B. P. Singh (Cham: Springer), 243-265.

Vandenkoornhuyse, P., Quaiser, A., Duhamel, M., Le Van, A., and Dufresne, A (2015). The importance of the microbiome of the plant holobiont. New Phytol. 206, 1196-1206. doi: 10.1111/nph.13312

Vaz, A. B. M., Fonseca, P. L. C., Badotti, F., Skaltsas, D., Tomé, L. M. R., Silva, A. C., et al. (2018). A multiscale study of fungal endophyte communities of the foliar endosphere of native rubber trees in Eastern Amazon. Sci. Rep. 8:16151. doi: 10.1038/s41598-018-34619-w

Vega, F. E. (2008). Insect pathology and fungal endophytes. J. Invertebr. Pathol. 98, 277-279. doi: 10.1016/j.jip.2008.01.008

Vidal, S., and Jaber, L. R. (2015). Entomopathogenic fungi as endophytes: plant-endophyte-herbivore interactions and prospects for use in biological control. Curr. Sci. 109, 46-54.

Waller, F., Achatz, B., Baltruschat, H., Fodor, J., Becker, K., Fischer, M., et al. (2005). The endophytic fungus Piriformospora indica reprograms barley to salt-stress tolerance, disease resistance, and higher yield. Proc. Natl. Acad. Sci. 102, 13386-13391. doi: 10.1073/pnas.0504423102

Wemheuer, B., Thomas, T., and Wemheuer, F. (2019). Fungal endophyte communities of three agricultural important grass species differ in their response towards management regimes. Microorganisms 7:37. doi: 10.3390/ microorganisms7020037 
Whipps, J. M. (2001). Microbial interactions and biocontrol in the rhizosphere. J. Exp. Bot. 52, 487-511. doi: 10.1093/jexbot/52.suppl_1.487

White, J. F., Kingsley, K. L., Zhang, Q., Verma, R., Obi, N., Dvinskikh, S., et al. (2019). Review: endophytic microbes and their potential applications in crop management. Pest Manag. Sci. 75, 2558-2565. doi: 10.1002/ps.5527

Woodward, C., Hansen, L., Beckwith, F., Redman, R. S., and Rodriguez, R. J. (2012). Symbiogenics: an epigenetic approach to mitigating impacts of climate change on plants. Hort Sci. 47, 699-703. doi: 10.21273/HORTSCI.47.6.699

Xia, Y., Sahib, M. R., Amna, A., Opiyo, S. O., Zhao, Z., and Gao, Y. G. (2019). Culturable endophytic fungal communities associated with plants in organic and conventional farming systems and their effects on plant growth. Sci. Rep. 9:1669. doi: 10.1038/s41598-018-38230-x

Xie, X. -G., Fu, W. -Q., Zhang, F. -M., Shi, X. -M., Zeng, Y. -T., Li, H., et al. (2017). The endophytic fungus Phomopsis liquidambari increases nodulation and $\mathrm{N}_{2}$ fixation in Arachis hypogaea by enhancing hydrogen peroxide and nitric oxide signalling. Microb. Ecol. 74, 427-440. doi: 10.1007/s00248-017-0944-8

Yadav, V., Kumar, M., Deep, D. K., Kumar, H., Sharma, R., Tripathi, T., et al. (2010). A phosphate transporter from the root endophytic fungus Piriformospora indica plays a role in phosphate transport to the host plant. J. Biol. Chem. 285, 26532-26544. doi: 10.1074/jbc.M110.111021
Young, C. A., Charlton, N. D., Takach, J. E., Swoboda, G. A., Trammell, M. A., Huhman, D. V., et al. (2014). Characterization of Epichloë coenophiala within the US: are all tall fescue endophytes created equal? Front. Chem. 2:95. doi: $10.3389 /$ fchem. 2014.00095

Yuan, J., Zhang, W., Sun, K., Tang, M. -J., Chen, P. -X., Li, X., et al. (2019). Comparative transcriptomics and proteomics of Atractylodes lancea in response to endophytic fungus Gilmaniella sp. AL12 reveals regulation in plant metabolism. Front. Microbiol. 10:1208. doi: 10.3389/fmicb.2019.01208

Conflict of Interest: The authors declare that the research was conducted in the absence of any commercial or financial relationships that could be construed as a potential conflict of interest.

Copyright (ㅇ 2020 Chitnis, Suryanarayanan, Nataraja, Prasad, Oelmüller and Shaanker. This is an open-access article distributed under the terms of the Creative Commons Attribution License (CC BY). The use, distribution or reproduction in other forums is permitted, provided the original author(s) and the copyright owner(s) are credited and that the original publication in this journal is cited, in accordance with accepted academic practice. No use, distribution or reproduction is permitted which does not comply with these terms. 